\title{
Prevalence of body image dissatisfaction and associated factors among physical education students
}

\author{
Prevalência de insatisfação com a imagem corporal \\ e fatores associados em universitários de educação física
}

Elisa Pinheiro Ferrari, ${ }^{1}$ Edio Luiz Petroski, ${ }^{2}$ Diego Augusto Santos Silva ${ }^{2}$

\begin{abstract}
Objective: To determine the prevalence of and factors associated with body image dissatisfaction among physical education students enrolled in a public university.

Methods: This study evaluated 236 students and assessed body image perception (silhouette scale), sociodemographic variables (sex, age, parental education, marital status, university course, work, living arrangement, study shift, and income), physical activity level (International Physical Activity Questionnaire - Short Version), dietary habits, tobacco use, excessive intake of alcohol (questions from the tobacco, alcohol and drugs, and nutrition domains of the FANTASTIC instrument), and nutritional status (body mass index [BMI]). Descriptive analysis, the chi-square test, Fisher's exact test, and crude and adjusted multinomial regression were used.

Results: The prevalence of body image dissatisfaction was $69.5 \% ; 44.1 \%$ were dissatisfied with excess weight. BMI $\geq 25.0$ $\mathrm{kg} / \mathrm{m}^{2}$ was associated with dissatisfaction with excess weight; factors associated with dissatisfaction with slimness were being male, eating an unhealthy diet, and smoking tobacco.

Conclusion: Our findings suggest that female college students with a BMI $\geq 25.0 \mathrm{~kg} / \mathrm{m}^{2}$ are more likely to present dissatisfaction with excess weight. Being male, eating an unhealthy diet, engaging in physical activity for $<739.61 \mathrm{~min} /$ week and smoking tobacco were the variables associated with dissatisfaction with thinness.
\end{abstract}

Keywords: Physical activity, nutritional status, students, body image.

\section{Resumo}

Objetivo: Verificar a prevalência e os fatores associados à insatisfação com a imagem corporal em universitários de educação física de uma universidade pública federal.

Métodos: Foram avaliados 236 universitários. Foram mensurados a percepção da imagem corporal (escala de silhueta), variáveis sociodemográficas (sexo, idade, escolaridade dos pais, estado civil, curso universitário, trabalho, moradia, turno de estudo e renda), nível de atividade física (Questionário Internacional de Atividade Física - Versão Curta), hábitos alimentares, uso de tabaco, consumo excessivo de bebidas alcoólicas (questões dos domínios tabaco, álcool e drogas, e nutrição do questionário Fantástico) e estado nutricional [índice de massa corporal (IMC)]. Utilizou-se análise descritiva, o teste do qui-quadrado, o teste exato de Fisher e regressão multinomial bruta e ajustada. Resultados: A prevalência de insatisfação com a imagem corporal foi de $69,5 \% ; 44,1 \%$ eram insatisfeitos por excesso de peso. IMC $\geq 25,0 \mathrm{~kg} / \mathrm{m}^{2}$ esteve associado a insatisfação por excesso; os fatores associados à insatisfação por magreza foram sexo masculino, alimentação inadequada e tabagismo.

Conclusão: Os resultados sugerem que acadêmicos do sexo feminino e com IMC $\geq 25,0 \mathrm{~kg} / \mathrm{m}^{2}$ têm mais chances de apresentar insatisfação por excesso de peso. Sexo masculino, alimentação inadequada, prática de atividade física $<739,61 \mathrm{~min} / \mathrm{semana}$ e uso de tabaco foram as variáveis associadas a insatisfação por magreza.

Descritores: Atividade motora, estado nutricional, estudantes, imagem corporal.

\footnotetext{
${ }^{1}$ Departamento de Educação Física, Centro de Desportos, Universidade Federal de Santa Catarina (UFSC), Florianópolis, SC, Brazil. Núcleo de Pesquisa em Cineantropometria e Desempenho Humano, UFSC, Florianópolis, SC, Brazil. Programa de Pós-Graduação em Educação Física, Centro de Desportos, UFSC, Florianópolis, SC, Brazil. Bolsista, Coordenação de Aperfeiçoamento de Pessoal de Nível Superior (CAPES). ${ }^{2}$ Departamento de Educação Física, Centro de Desportos, UFSC, Florianópolis, SC, Brazil. Núcleo de Pesquisa em Cineantropometria e Desempenho Humano, UFSC, Florianópolis, SC, Brazil. Programa de Pós-Graduação em Educação Física, Centro de Desportos, UFSC, Florianópolis, SC, Brazil.

Financial support: none.

Submitted Jan 12 2012, accepted for publication Sep 18 2012. No conflicts of interest declared concerning the publication of this article. Suggested citation: Ferrari EP, Petroski EL, Silva DA. Prevalence of body image dissatisfaction and associated factors among physical education students. Trends Psychiatry Psychother. 2013;35(2):119-27.
} 


\section{Introduction}

Factors such as urbanization, economic growth, and recent technological and cultural changes have motivated an increased intake of saturated fat, with the consequent development of overweight and obesity in the Brazilian population. ${ }^{1}$ Conversely, the beauty ideals promoted in the mass media point to increasingly slimmer silhouettes and heavily muscled bodies (for females and males, respectively) as the only acceptable or pleasing patterns, provoking body image dissatisfaction in those who are unable to comply with them. This phenomenon has been widely observed and has been referred to as a negative subjective assessment of one's physical appearance. ${ }^{2}$

In the transition from adolescence to adult age, a phase frequently observed among university students, new individual and social skills are being acquired, including insertion in a new social environment, imposition of new obligations, and less contact with family members. Moreover, the vulnerability to predominant social models and representations commonly observed in this stage tends to predispose this population to the development of body image dissatisfaction. ${ }^{3}$

Both the Brazilian and the international literature have reported prevalence rates of body image dissatisfaction above $50 \%$ among university students. ${ }^{4-7}$ In courses where physical appearance is important, e.g., physical education, high levels of dissatisfaction are even more common, reflecting the interest of these students in body-related issues. ${ }^{8}$ This finding has provided grounds for concern, as high levels of body image dissatisfaction may lead to the development of eating disorders, low self-esteem, and excessive physical activity, especially among women striving to achieve the slim body ideal imposed by society. ${ }^{9,10}$

Health-related behaviors, including excessive alcohol use, physical activity, dietary habits, and tobacco use, are important when discussing body image dissatisfaction, as they may be adopted in the search for an ideal body weight. ${ }^{5,11,12}$ Also, several studies have investigated sociodemographic characteristics, such as sex, age, parental education, marital status, university course, work, living arrangement, study shift, and income. 5,6,13,14 Some of those studies failed to find an association between body image and study shift, income, and occupation among university students. 5,15 Other studies, in turn, found associations between income and body image, i.e., women with a higher income were shown to present higher levels of body image dissatisfaction. ${ }^{14}$ Sex has also been associated with body image dissatisfaction, with women showing a desire to become slimmer and men a desire to increase their body outline. ${ }^{6}$ In this sense, and based on the lack of consensus in the relevant literature, the assessment of factors associated with body image dissatisfaction in this specific population becomes extremely relevant, so that we can achieve a better understanding of the variables associated with this phenomenon among university students, as well as the direction of existing associations.

The objective of the present study was to assess the prevalence of body image dissatisfaction and its association with sociodemographic characteristics (sex, age, parental education, marital status, university course, work, living arrangement, study shift, income), health-related behaviors (physical activity, dietary habits, tobacco use, excessive alcohol intake), and nutritional status in physical education students enrolled in a public university.

\section{Methods}

This study used data from the database of a research project designed to investigate physical fitness and health among students attending Universidade Federal de Santa Catarina (UFSC), a public university in Florianópolis, southern Brazil. The research protocol was approved by the Research Ethics Committee of the same institution (protocol no. 096/2007).

\section{Population and sample}

The study population comprised 565 university students (300 males) attending the course of physical education in 2008 at UFSC; 182 were enrolled in the bachelor's specialty, and 383 in the teaching specialty.

All subjects enrolled in both specialties were invited to participate in the study and were asked to sign an informed consent form prior to their inclusion.

Data collection lasted for 1 week and was conducted online at the sports department's computer laboratory. This collection method was chosen in an attempt to reduce the number of errors during instrument application, and also for logistic reasons, as the database was automatically created and updated as instruments were filled, excluding the possibility of typing errors. The team responsible for data collection remained available to students throughout the session to clarify any doubts that might come up while answering the questionnaire. A total of 236 students attended the data collection sessions, namely, 127 males and 109 females, accounting for $41.8 \%$ of the total target population $(42.3 \%$ of males and $41.1 \%$ of females). 


\section{Instruments and procedures}

\section{Dependent variable}

Data related to perceived body image were obtained using a scale comprising nine body silhouettes, numbered 1 to 9 , representing a continuum from thinness (silhouette 1 ) to severe obesity (silhouette 9). ${ }^{16}$ The set of silhouettes was shown to students, and then the following questions were asked: 1) which of these silhouettes best represents your current physical appearance? 2) which of these silhouettes would you like to have? Body image dissatisfaction was assessed based on the difference between the current and ideal silhouettes indicated. Differences equal to zero indicated satisfaction, and differences different from zero, dissatisfaction. Positive differences were considered suggestive of dissatisfaction with excess weight, whereas negative differences indicated dissatisfaction with slimness.

\section{Independent variables}

The following independent variables were assessed: sociodemographic characteristics (sex, age, parental education, marital status, university course, work, living arrangement, study shift, and income); health-related behaviors (level of physical activity, dietary habits, tobacco use, and excessive intake of alcohol); and nutritional status.

Sociodemographic information was obtained using a self-report questionnaire. Variables were categorized as follows: sex (male and female), age ( $>20$ and $\leq$ 20 years), parental (mother and father) education ( $>8$ and $\leq 8$ years of education), marital status (single and married), university course (bachelor and teaching), work (yes and no), living arrangement (living with someone and alone), and study shift (morning and evening). Income was assessed by asking what the family income was and offering five answer options, as follows: up to one minimum wage, one to three, three to six, six to 10 , and over 10 minimum wages (the Brazilian minimum wage in 2008 was $R \$ 415.00$, equivalent to US\$207.50). Taking into consideration the distribution previously observed, income categories were dichotomized into up to six minimum wages and over six minimum wages.

With regard to health-related behaviors, the level of physical activity was measured using the International Physical Activity Questionnaire (IPAQ), version 8 (short version, last week). ${ }^{17}$ In line with the current physical activity recommendation of 150 minutes per week, the present study considered as little active individuals who did not engage in physical activities for a minimum of 150 minutes per week. In our sample, the percentage of physically inactive university students was $0.4 \%$. Because of the low-frequency of physical inactivity, data were categorized into quartiles according to the weekly number of minutes spent engaging in physical activity, as follows: quartile 1 (0-600 min/week), quartile 2 (601$1,025 \mathrm{~min} /$ week), quartile 3 (1,026-1,740 min/week), and quartile 4 (>1,740 min/week). For statistical analysis purposes, subjects in the first quartile were referred to as the least active, those in the second quartile active intermediate I, in the third, active intermediate II, and in the last quartile, the most active. ${ }^{18}$

Dietary habits, tobacco use, and excessive intake of alcohol were assessed using specific questions of the nutrition, tobacco, and alcohol and drugs domains, respectively, of the FANTASTIC instrument, ${ }^{19}$ translated and validated for use in Brazilian young adults. ${ }^{20}$

Dietary habits were assessed using the statement "I eat a balanced diet." According to the questionnaire, a balanced diet consists of 5 to 12 daily portions of grains and cereal, 5 to 10 daily portions of fruits and vegetables, 2 to 3 portions of meat or alternatives, and 2 to 4 daily portions of milk and derivatives. Five options of answers were available for this question: almost never, rarely, sometimes, often, and almost always. This variable was also dichotomized into healthy diet, including almost always and often, and unhealthy diet, including almost never, rarely, and sometimes.

Tobacco use was analyzed using the "I smoke cigarettes" statement. This variable was categorized into smoker (those smoking over 10 cigarettes a day and 1-10 cigarettes a day) and non-smokers (those who denied having smoked any cigarette in the last 6 months, last year, and in the last 5 years). Studies have defined smokers as people who report having smoked one or more cigarettes in the last 30 days. ${ }^{21,22}$

Excessive intake of alcohol was assessed using the statement "My weekly intake of alcohol is..." A dose of alcohol was defined as a can of beer $(340 \mathrm{ml})$, or a glass of wine $(142 \mathrm{ml}$ ), or a dose of distilled spirit (42 $\mathrm{ml}$ ). Again, alcohol intake may be classified into five categories, but in this study only two were considered, namely, excessive intake of alcohol (over 20 doses and 13-20 doses) and non-excessive intake of alcohol (1112 doses, 8-10 doses, and up to 7 doses). The literature defines as an excessive intake of alcohol the consumption of $\geq 14$ doses/week. ${ }^{23,24}$

Body mass and height were self-reported. The validity of these measures has been demonstrated in the Brazilian adult population. ${ }^{25}$ Body mass index (BMI) was stratified using the cutoff points established by the World Health Organization (WHO). ${ }^{26}$ Because of the low frequencies observed for underweight and obesity, BMI 
was divided into two categories, namely, normal weight (underweight and normal weight) and excess weight (overweight and obesity).

\section{Statistical analysis}

Data were analyzed using descriptive statistics, and results expressed using relative and absolute frequencies. Associations between body image perception and sociodemographic characteristics, health-related behaviors, and nutritional status were assessed using the chi-square test and Fisher's exact test.

Multinomial logistic regression was used to estimate the association between different independent variables and the dependent variable body image perception, categorized into satisfied with body image (reference category), dissatisfied with excess weight, and dissatisfied with slimness. Odds ratios (OR) and respective 95\% confidence intervals $(95 \% \mathrm{CI})$ were calculated. First, crude analysis was conducted to assess the effect of variables on perceived body image. Subsequently, the analysis was adjusted for all independent variables. Data were analyzed using the Statistical Package for the Social Sciences (SPSS) version 15.0. Significance was set at 5\%.

\section{Results}

Table 1 shows sample distribution according to perceived body image and independent variables. The prevalence of body image dissatisfaction was $69.5 \%$; in this group, $44.1 \%$ were dissatisfied with excess weight, and the remaining $25.4 \%$ with slimness. Most of the university students assessed were male $(53.8 \%)$, aged $>20$ years $(56.8 \%)$, had a family income above six minimum wages $(51.7 \%)$, reported over 8 years of education for mothers $(90.3 \%)$ and fathers $(87.7 \%)$, were single $(94.9 \%)$, were enrolled in the teaching specialty $(52.5 \%)$, were not employed (61\%), lived with someone (93.2\%), studied in the morning $(58.1 \%)$, ate a healthy diet $(81.4 \%)$, were non-smokers $(85.8 \%)$, had normal weight $(79.2 \%)$, and did not consume excessive amounts of alcohol (93.6\%).

Table 2 shows the associations between perceived body image and the independent variables assessed. The results revealed that dissatisfaction with excess weight was more prevalent among women, non-smokers, and those with excess weight. Conversely, male students, those eating an unhealthy diet, smoking, and showing a healthy nutritional status more frequently reported dissatisfaction with slimness.

In the crude multinomial regression analysis, a BMI $\geq 25.0 \mathrm{~kg} / \mathrm{m}^{2}$ was associated with dissatisfaction with excess weight. In the adjusted analysis, factors
Table 1 - Sample distribution according to perceived body image, sociodemographic characteristics, health-related behaviors, and nutritional status

\begin{tabular}{|c|c|c|}
\hline Variable & $\mathbf{n}$ & $\%$ \\
\hline \multicolumn{3}{|l|}{ Body image perception } \\
\hline Satisfied & 72 & 30.5 \\
\hline Dissatisfied with excess weight & 104 & 44.1 \\
\hline Dissatisfied with slimness & 60 & 25.4 \\
\hline \multicolumn{3}{|l|}{ Sex } \\
\hline Female & 109 & 46.2 \\
\hline Mal & 127 & 53.8 \\
\hline \multicolumn{3}{|l|}{ Age } \\
\hline$>20$ years & 134 & 56.8 \\
\hline$\leq 20$ years & 102 & 43.2 \\
\hline \multicolumn{3}{|l|}{ Family income } \\
\hline$>6$ minimum wages & 122 & 51.7 \\
\hline$\leq 6$ minimum wages & 114 & 48.3 \\
\hline \multicolumn{3}{|l|}{ Mother's education level } \\
\hline$>8$ years & 213 & 90.3 \\
\hline$\leq 8$ years & 23 & 9.7 \\
\hline \multicolumn{3}{|l|}{ Father's education level } \\
\hline$>8$ years & 207 & 87.7 \\
\hline$\leq 8$ years & 29 & 12.3 \\
\hline \multicolumn{3}{|l|}{ Marital status } \\
\hline Married & 12 & 5.1 \\
\hline Single & 224 & 94.9 \\
\hline \multicolumn{3}{|l|}{ Course specialty } \\
\hline Bachelor & 112 & 47.5 \\
\hline Teaching & 124 & 52.5 \\
\hline \multicolumn{3}{|l|}{ Work } \\
\hline Yes & 92 & 39.0 \\
\hline No & 144 & 61.0 \\
\hline \multicolumn{3}{|l|}{ Living arrangement } \\
\hline Lives with someone & 220 & 93.2 \\
\hline Lives alone & 16 & 6.8 \\
\hline \multicolumn{3}{|l|}{ Study shift } \\
\hline Morning & 99 & 41.9 \\
\hline Evening & 137 & 58.1 \\
\hline \multicolumn{3}{|l|}{ Physical activity } \\
\hline Most active & 51 & 21.5 \\
\hline Active intermediate II & 60 & 25.3 \\
\hline Active intermediate I & 58 & 24.5 \\
\hline Least active & 67 & 28.3 \\
\hline \multicolumn{3}{|l|}{ Diet } \\
\hline Healthy & 192 & 81.4 \\
\hline Unhealthy & 44 & 18.6 \\
\hline \multicolumn{3}{|l|}{ Tobacco use } \\
\hline No & 226 & 95.8 \\
\hline Yes & 10 & 4.2 \\
\hline \multicolumn{3}{|l|}{ Nutritional status } \\
\hline Normal weight & 187 & 79.2 \\
\hline Excess weight & 44 & 18.6 \\
\hline \multicolumn{3}{|l|}{ Excessive alcohol intake } \\
\hline No & 221 & 93.6 \\
\hline Yes & 15 & 6.4 \\
\hline
\end{tabular}


Table 2 - Prevalence of dissatisfaction with slimness and excess weight according to the independent variables assessed, \% ( $\mathrm{n}$ )

\begin{tabular}{|c|c|c|c|c|}
\hline Variable & Satisfied & $\begin{array}{l}\text { Dissatisfied with } \\
\text { excess weight }\end{array}$ & $\begin{array}{c}\text { Dissatisfied } \\
\text { with slimness }\end{array}$ & $\mathbf{p}$ \\
\hline \multicolumn{5}{|l|}{ Sex } \\
\hline Female & $30.3(33)$ & $54.1(59)$ & $15.6(17)$ & \multirow[t]{2}{*}{$0.002^{*+}$} \\
\hline Male & 30.7 (39) & $35.4(45)$ & $33.9(43)$ & \\
\hline \multicolumn{5}{|l|}{ Age } \\
\hline$>20$ years & $33.6(45)$ & $42.5(57)$ & $23.9(32)$ & \multirow[t]{2}{*}{$0.493^{+}$} \\
\hline$\leq 20$ years & $26.5(27)$ & $46.1(47)$ & $27.5(28)$ & \\
\hline \multicolumn{5}{|l|}{ Family income } \\
\hline$>6$ minimum wages & $27.0(33)$ & $43.4(53)$ & $29.5(36)$ & \multirow[t]{2}{*}{$0.263^{+}$} \\
\hline$\leq 6$ minimum wages & $34.2(39)$ & $44.7(51)$ & $21.1(24)$ & \\
\hline \multicolumn{5}{|l|}{ Mother's education level } \\
\hline$>8$ years & $29.6(63)$ & $45.5(97)$ & $24.9(53)$ & \multirow[t]{2}{*}{$0.378^{+}$} \\
\hline$\leq 8$ years & $39.1(9)$ & $30.4(7)$ & $30.4(7)$ & \\
\hline \multicolumn{5}{|l|}{ Father's education level } \\
\hline$>8$ years & $30.0(62)$ & $43.5(90)$ & $26.6(55)$ & \multirow[t]{2}{*}{$0.556^{+}$} \\
\hline$\leq 8$ years & $34.5(10)$ & $48.3(14)$ & $17.2(5)$ & \\
\hline \multicolumn{5}{|l|}{ Marital status } \\
\hline Married & $8.3(1)$ & $75.0(9)$ & $16.7(2)$ & \multirow[t]{2}{*}{$0.091^{\neq}$} \\
\hline Single & $31.7(71)$ & $42.4(95)$ & $25.9(58)$ & \\
\hline \multicolumn{5}{|l|}{ Course specialty } \\
\hline Bachelor & $29(36)$ & $41.9(52)$ & $29(36)$ & \multirow[t]{2}{*}{$0.408^{+}$} \\
\hline Teaching & $32.1(36)$ & $46.4(52)$ & $21.4(24)$ & \\
\hline \multicolumn{5}{|l|}{ Work } \\
\hline Yes & $33.3(48)$ & $41.0(59)$ & $25.7(37)$ & \multirow[t]{2}{*}{$0.411^{+}$} \\
\hline No & $26.1(24)$ & $48.9(45)$ & $25(23)$ & \\
\hline \multicolumn{5}{|l|}{ Living arrangement } \\
\hline Lives with someone & $31.4(69)$ & $44.5(98)$ & $24.1(53)$ & \multirow[t]{2}{*}{$0.228^{\ddagger}$} \\
\hline Lives alone & $18.8(3)$ & $37.5(6)$ & $43.8(7)$ & \\
\hline \multicolumn{5}{|l|}{ Study shift } \\
\hline Morning & $32.3(32)$ & $46.5(46)$ & $21.2(21)$ & \multirow[t]{2}{*}{$0.450^{+}$} \\
\hline Evening & $29.2(40)$ & $42.3(58)$ & $28.5(39)$ & \\
\hline \multicolumn{5}{|l|}{ Physical activity } \\
\hline Most active & $27.5(14)$ & $51.0(26)$ & $21.6(11)$ & \multirow[t]{4}{*}{$0.111^{+}$} \\
\hline Active intermediate II & $43.3(26)$ & $38.3(23)$ & $18.3(11)$ & \\
\hline Active intermediate I & $27.6(16)$ & $48.3(28)$ & $24.1(14)$ & \\
\hline Least active & $23.9(16)$ & $40.3(27)$ & $35.8(24)$ & \\
\hline \multicolumn{5}{|l|}{ Diet } \\
\hline Healthy & $33.3(64)$ & $44.3(85)$ & $22.4(43)$ & $0.040 *+$ \\
\hline Unhealthy & $18.2(8)$ & $43.2(19)$ & $38.6(17)$ & \\
\hline Tobacco use & & & & \\
\hline No & $31.4(71)$ & $44.7(101)$ & $23.9(54)$ & $0.045^{* \neq}$ \\
\hline Yes & $10(1)$ & $30(3)$ & $60(6)$ & \\
\hline Nutritional status & & & & \\
\hline Normal weight & $34.2(64)$ & $35.8(67)$ & $29.9(56)$ & $<0.001^{*}$ \\
\hline Excess weight & $13.6(6)$ & $84.1(37)$ & $2.3(1)$ & \\
\hline Excessive alcohol intake & & & & \\
\hline No & $30.8(68)$ & $43(95)$ & $26.2(58)$ & $0.458^{\neq}$ \\
\hline Yes & $26.7(4)$ & $60(9)$ & $13.3(2)$ & \\
\hline
\end{tabular}


Table 3 - Odds ratio and confidence intervals of crude and adjusted multinomial logistic regression analysis of body image perception (reference category = satisfied with body image), OR $(95 \% \mathrm{CI})$

\begin{tabular}{|c|c|c|c|c|}
\hline \multirow[b]{2}{*}{ Variable } & \multicolumn{2}{|c|}{ Dissatisfied with excess weight } & \multicolumn{2}{|c|}{ Dissatisfied with slimness } \\
\hline & Crude analysis & Adjusted analysis* & Crude analysis & Adjusted analysis* \\
\hline \multicolumn{5}{|l|}{ Sex } \\
\hline Female & 1 & 1 & 1 & 1 \\
\hline Male & $0.64(0.35-1.18)$ & $0.32(0.15-0.69)$ & $2.14(1.03-4.43)$ & $2.73(1.16-6.45)$ \\
\hline \multicolumn{5}{|c|}{ 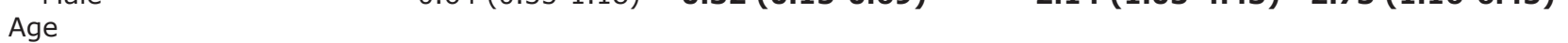 } \\
\hline$>20$ years & 1 & 1 & 1 & 1 \\
\hline$\leq 20$ years & $1.37(0.74-2.54)$ & $1.42(0.67-3.03)$ & $1.46(0.73-2.93)$ & $1.69(0.71-4.05)$ \\
\hline \multicolumn{5}{|l|}{ Family income } \\
\hline$>6$ minimum wages & 1 & 1 & 1 & 1 \\
\hline$\leq 6$ minimum wages & $0.81(0.45-1.49)$ & $1.32(0.64-2.75)$ & $0.56(0.28-1.13)$ & $0.50(0.22-1.15)$ \\
\hline \multicolumn{5}{|l|}{ Mother's education level } \\
\hline$>8$ years & 1 & 1 & 1 & 1 \\
\hline$\leq 8$ years & $0.50(0.18-1.42)$ & $0.44(0.11-1.72)$ & $0.92(0.32-2.65)$ & $1.69(0.45-6.37)$ \\
\hline \multicolumn{5}{|l|}{ Father's education level } \\
\hline$>8$ years & 1 & 1 & 1 & 1 \\
\hline$\leq 8$ years & $0.96(0.40-2.31)$ & $1.02(0.33-3.22)$ & $0.56(0.18-1.75)$ & $0.67(0.16-2.85)$ \\
\hline \multicolumn{5}{|l|}{ Marital status } \\
\hline Married & 1 & 1 & 1 & 1 \\
\hline Single & $0.15(0.02-1.2)$ & $0.13(0.13-1.24)$ & $0.41(0.04-4.62)$ & $0.16(0.01-2.13)$ \\
\hline \multicolumn{5}{|l|}{ Course specialty } \\
\hline Bachelor & 1 & 1 & 1 & 1 \\
\hline Teaching & $1(0.55-1.82)$ & $1.66(0.38-7.27)$ & $0.67(0.33-1.33)$ & $0.70(0.14-3.44)$ \\
\hline \multicolumn{5}{|l|}{ Work } \\
\hline Yes & 1 & 1 & 1 & 1 \\
\hline No & $1.52(0.82-2.85)$ & $1.77(0.83-3.75)$ & $1.24(0.61-2.54)$ & $1.23(0.53-2.86)$ \\
\hline \multicolumn{5}{|l|}{ Living arrangement } \\
\hline Lives with someone & 1 & 1 & 1 & 1 \\
\hline Lives alone & $1.41(0.34-5.82)$ & $1.52(0.31-7.33)$ & $3.04(0.75-12.31)$ & $2.79(0.59-13.13)$ \\
\hline \multicolumn{5}{|l|}{ Study shift } \\
\hline Morning & 1 & 1 & 1 & 1 \\
\hline Evening & $1.01(0.55-1.84)$ & $1.82(0.40-8.27)$ & $1.49(0.73-3.00)$ & $1.17(0.23-6.09)$ \\
\hline \multicolumn{5}{|l|}{ Physical activity } \\
\hline Most active & 1 & 1 & 1 & 1 \\
\hline Active intermediate II & $1.85(0.93-3.68)$ & $0.61(0.23-1.63)$ & $0.54(0.19-1.55)$ & $0.59(0.18-1.94)$ \\
\hline Active intermediate I & $0.94(0.38-2.30)$ & $1.29(0.46-3.62)$ & $1.11(0.38-3.24)$ & $1.53(0.44-5.31)$ \\
\hline Least active & $0.91(0.37-2.23)$ & $0.88(0.31-2.49)$ & $1.91(0.69-5.25)$ & $2.16(0.66-7.00)$ \\
\hline \multicolumn{5}{|l|}{ Diet } \\
\hline Healthy & 1 & 1 & 1 & 1 \\
\hline Unhealthy & $1.79(0.74-4.34)$ & $1.37(0.49-3.86)$ & $3.16(1.25-7.98)$ & $2.56(0.90-7.27)$ \\
\hline \multicolumn{5}{|l|}{ Tobacco use } \\
\hline No & 1 & 1 & 1 & 1 \\
\hline Yes & $2.11(0.21-20.69)$ & $3.80(0.34-41.95)$ & $7.89(0.92-67.48)$ & $3.80(0.34-41.90)$ \\
\hline \multicolumn{5}{|l|}{ Nutritional status } \\
\hline Normal weight & 1 & 1 & 1 & 1 \\
\hline Excess weight & $5.89(2.33-14.9)$ & $11.80(3.99-34.88)$ & $0.19(0.02-1.63)$ & $0.101(0.01-1.00)$ \\
\hline \multicolumn{5}{|l|}{ Excessive alcohol intake } \\
\hline No & 1 & 1 & 1 & 1 \\
\hline Yes & $1.61(0.48-5.44)$ & $2.19(0.54-8.80)$ & $0.59(0.10-3.32)$ & $2.19(0.55-8.80)$ \\
\hline
\end{tabular}

$95 \% \mathrm{CI}=95 \%$ confidence interval; OR $=$ odds ratio.

Values in bold are significant $(p<0.05)$.

* Adjusted for all independent variables. 
associated with dissatisfaction were a BMI $\geq 25.0 \mathrm{~kg} /$ $\mathrm{m}^{2}(\mathrm{OR}=11.80 ; 95 \% \mathrm{CI} 3.99-34.88)$ and being male $(\mathrm{OR}=0.32 ; 95 \% \mathrm{CI} 0.15-0.69)$. Male sex showed an inverse association with dissatisfaction with excess weight, suggesting that females were more frequently dissatisfied with excess weight (Table 3).

In the crude analysis of dissatisfaction with slimness (Table 3), the following factors were associated with the outcome: male sex, engaging in physical activity for < $739.61 \mathrm{~min} /$ week, eating an unhealthy diet, and smoking. In the adjusted analysis, male sex $(O R=2.73$; $95 \%$ CI 1.16-6.45) and engaging in physical activity for < $739.61 \mathrm{~min} /$ week $(\mathrm{OR}=2.39 ; 95 \% \mathrm{CI} 1.01-5.68)$ remained associated with dissatisfaction with slimness. Also, excess weight ( $\mathrm{OR}=0.10 ; 95 \% \mathrm{CI}$ 0.01-1.01) showed an inverse association with dissatisfaction with slimness, suggesting that subjects with normal weight were more frequently dissatisfied with slimness.

\section{Discussion}

The main findings of the present study were a higher frequency of body image dissatisfaction with excess weight among females and students with a BMI $\geq 25.0$ $\mathrm{kg} / \mathrm{m}^{2}$, as well as a higher degree of dissatisfaction with slimness among male students, smokers, and students eating an unhealthy diet.

With regard to body image dissatisfaction, the prevalence observed in our sample $(69.5 \%)$ is in line with data reported for physical education students attending Universidade Estadual de Ponta Grossa, state of Paraná, among whom $61.2 \%$ were dissatisfied. ${ }^{5}$ Another study assessing students enrolled in several courses at UFSC found a prevalence of $77.6 \%$ of body image dissatisfaction. ${ }^{6}$ These results suggest that, regardless of the field of study, university students present high prevalence rates of body image dissatisfaction, providing grounds for concern with regard to the consistent association between this phenomenon and the development of eating disorders, depression, low selfesteem, and a negative quality of life perception. ${ }^{27}$

Regarding the association between perceived body image and BMI, our study identified that overweight/ obesity was associated with the desire to reduce the silhouette. This finding corroborates previous studies $6,10,28$ and shows that the ideal body image among university students reflects the same slim and muscled patterns (for females and males, respectively) currently praised in sociocultural contexts, where fat or a higher body weight are seen as a stigma of ugliness, causing individuals with a higher BMI to feel uncomfortable and concerned with their body image. This finding is especially important if we take into consideration that BMI has been shown to strongly influence the adoption of abnormal behaviors, anorexia, bulimia, and vigorexia: even after adjustment for socioeconomic and demographic variables, the risk of developing such behaviors was two-fold higher in subjects with a BMI $\geq 25.0 \mathrm{~kg} / \mathrm{m}^{2} .^{29}$

When analyzing the association between perceived body image and sex, evidence suggests that, whereas men tend to show dissatisfaction with slimness, women tend to report dissatisfaction with excess weight. ${ }^{5,6}$ In our study, being male was associated with a higher likelihood of showing dissatisfaction with slimness. Conversely, being female was associated with a higher chance of dissatisfaction with excess weight. These results reflect differences instilled in body image patterns praised in the mass media for males and females. In this sense, reflexive actions should be implemented in the university setting to discuss strategies aimed at improving body image self-acceptance; the literature has pointed to the effectiveness of different types of interventions in reducing the levels of body image dissatisfaction, e.g., strategies aimed at reducing cognitive dissonance ${ }^{30}$ and minimizing the effects of body images praised in the internet and mass media. ${ }^{31}$

In our sample, no association was observed between the level of physical activity and perceived body image. A previous study involving physical education students from Universidade Estadual de Ponta Grossa also failed to find this association. ${ }^{5}$ Conversely, another study assessing young adults from the U.S. via telephone calls observed that individuals not satisfied with their weight showed lower levels of physical activity when compared with satisfied ones. ${ }^{13}$ This lack of consensus may be explained by methodological differences across the studies. For example, in the former study, ${ }^{5}$ a silhouette scale was used, whereas in the latter, ${ }^{12}$ body image dissatisfaction was assessed using the question "How do you feel in relation to your body weight at this moment?" Despite the controversial results available, a possible explanation for the absence of association between body image dissatisfaction and physical activity levels in our sample could be the fact that being physically active or inactive did not influence perceived body image in the students here analyzed, suggesting a stronger effect of other factors on the outcome of interest.

The adoption of health-related behaviors such as eating an unhealthy diet or smoking has been associated with body image dissatisfaction. Some studies have indicated that dissatisfied individuals tend to start smoking and eating an unhealthy/restrictive diet as a means to obtain a slimmer or more muscled body. ${ }^{11,12}$ In the present study, the crude effect of these two variables (diet and tobacco use) on perceived body image was not confirmed in the adjusted 
analysis, suggesting a role of other variables, e.g. level of physical activity and nutritional status, in the association between dietary habits and tobacco use and body image dissatisfaction. Moreover, the lack of association between excessive alcohol intake and perceived body image in our students may also be explained by the presence of other variables in the analysis.

Sociodemographic variables (age, parental education, marital status, university course, work, living arrangement, study shift, and income) were not associated with body image perception. These results are in line with previous studies that also failed to identify associations between perceived body image and age, study shift, occupation, and income. ${ }^{5,15}$ Conversely, they differ from other studies that have reported associations with age and income. ${ }^{14}$ Further studies are warranted to continue investigating this topic so as to identify the direction of associations between body image perception and different sociodemographic variables.

Some limitations deserve to be discussed. First and foremost, the cross-sectional design of the study prevents us from establishing a causal relationship between the variables. Second, the use of a silhouette scale to assess body image is limited by the two-dimensional nature of the images, which therefore do not represent the individual as a whole and do not reflect the distribution of subcutaneous fat and other anthropometric aspects implicated in the concept of body image.

Notwithstanding, previous studies have suggested strong correlations between BMI and perceived body image. ${ }^{4}$ Third, the instrument used to assess dietary habits did not allow to identify whether diet inadequacy was characterized by excessive intake (beyond the recommended daily portions), or deficient intake (below the recommended portions).

Conversely, a strength of the study is that our findings can be used to alert physical education professionals with regard to the need to implement interventions based on the ideals praised in the media, which usually contribute to increase body image dissatisfaction and to the adoption of unhealthy, even noxious, habits. Another strength was the use of an online questionnaire, which allowed the automatic creation and update of the database, as questions were answered, and eliminated typing errors.

\section{Conclusion}

The prevalence of body image dissatisfaction among the university students assessed was high. Dissatisfaction with excess weight was associated with female sex and a BMI $\geq 25.0 \mathrm{~kg} / \mathrm{m}^{2}$. Being male, eating an unhealthy diet, and smoking were the variables associated with dissatisfaction with slimness.

Our results underscore the need to implement interventions aimed at increasing self-acceptance and self-awareness in the academic setting through the adoption of healthy behaviors, such as regular physical activity and a balanced diet. These interventions could, in turn, help improve body image satisfaction, reduce BMI in people above normal weight, and motivate a more reflexive attitude towards body image ideals praised in society, especially in terms of their association with healthy vs. unhealthy habits. We strongly believe that this type of strategy could promote the adoption of healthier habits and thus improve daily living.

Future studies should analyze the influence of healthrelated behaviors (physical activity, dietary habits, and tobacco use) on perceived body image among university students, in order to confirm the findings here reported and further improve our knowledge on the topic. Such studies could also help decrease the rates of body image dissatisfaction and the adoption of noxious habits resulting from difficulties self-accepting one's own body image. 


\section{References}

1. Ribeiro RQ, Lotufo PA, Lamounier JA, Oliveira RG, Soares JF, Botter DA. Fatores adicionais de risco cardiovascular associados ao excesso de peso em crianças e adolescentes: o estudo do coração de Belo Horizonte. Arq Bras Cardiol. 2006;86:408-18.

2. Warren CS, Gleaves DH, Capeda BA, Fernandez MC, Rodriguez RS. Ethnicity as a protective factor against internalization of a thin ideal and body dissatisfaction. Int J Eat Disord. 2005;37:241-9

3. França CB, Colares VA. Estudo comparativo de condutas de saúde entre universitários no início e no final do curso. Rev Saude Publica. 2008;42:420-7.

4. Coqueiro RS, Petroski EL, Pelegrini A, Barbosa AR. Insatisfação com a imagem corporal: avaliação comparativa da associação com estado nutricional em universitários. Rev Psiquiatr Rio Gd Sul. 2008;30:31-8.

5. Rech CR, Araújo EDS, Vanat JR. Autopercepção da imagem corporal em estudantes do curso de educação física. Rev Bras Educ Fis Esporte. 2010;24:285-92.

6. Quadros TMB, Gordia AP, Martins CR, Silva DAS, Ferrari EP, Petroski EL. Imagem corporal em universitários: associação com estado nutricional e sexo. Motriz Rev Educ Fis. 2010;16:78-85.

7. Grossbard JR, Lee CM, Neighbors C, Larimer ME. Body image concerns and contingent self-esteem in male and female college students. Sex Roles. 2008;60:198-207.

8. O'Brien KS, Hunter JA. Body esteem and eating behaviors in female physical education students. Eat Weight Disord. 2006;11:57-60.

9. Almeida GA, Santos JE, Paisan SR, Loureira SR. Percepção de tamanho e forma corporal de mulheres: um estudo exploratório. Psicol Estud. 2005;10:27-35.

10. Kakeshita IS, Almeida SS. Relação entre índice de massa corporal e a percepção da auto-imagem em universitários. Rev Saude Publica. 2006;40:497-504.

11. Clark MM, Croghan IT, Reading S, Schoroeder DR, Stoner $S M$, Patten $C A$, et al. The relationship of body image dissatisfaction to cigarette smoking in college students. Body Image. $2005 ; 2: 263-70$.

12. Jaworowska A, Bazylak G. An outbreak of body weight dissatisfaction associated with self-perceived BMI and dieting among female pharmacy students. Biomed Pharmacother. 2009;63:679-92.

13. Kruger J, Chong-Do L, Ainsworth BE, Macera CA. Body size satisfaction and physical activity levels among men and women. Obesity. 2008;16:1976-9.

14. Wardle J, Griffith J. Socioeconomic status and weight control practices in British adults. J Epidemiol Community Health. 2001; 55:185-90.

15. Costa LCF, Vasconcelos FAG. Influência de fatores socioeconômicos, comportamentais e nutricionais na insatisfação com a imagem corporal de universitárias em Florianópolis, SC. Rev Bras Epidemiol. 2010;13:665-76.

16. Stunkard A, Sorensen T, Schulsinger F. Use of the Danish Adoption Register for the study of obesity and thinness. In: Kety SS, Rowland LP, Sidman RL, Matthysse SW, editors. The genetics of neurological and psychiatric disorders. New York: Raven Press; 1983. p. 115-20.
17. Matsudo S, Araujo T, Matsudo V, Andrade D, Andrade E, Oliveira LC, et al. Questionário Internacional de Atividade Física (IPAQ): estudo de validade e reprodutibilidade no Brasil. Rev Bras Ativ Fis Saude. 2001;6:5-18.

18. IPAQ Executive Committee. The International Physical Activity Questionnaire: summary report of the reliability and validity studies. http://www.ipaq.ki.se/questionnaires/ IPAQSummaryReport03-01.pdf. Accessed 2012 Sep 18.

19. Wilson DMC, Nielsen E, Ciliska D. Lifestyle assessment: testing the FANTASTIC instrument. Can Fam Physician. 1984;30:1863-6.

20.Rodriguez-Añez CR, Reis RS, Petroski EL. Brazilian version of a lifestyle questionnaire: translation and validation for young adults. Arq Bras Cardiol. 2008;91:92-8

21. Halty LS, Hunntnner MD, Oliveira-Netto I, Fenker T, Paqualini $T$, Lempek $B$, et al. Pesquisa sobre tabagismo entre médicos de Rio Grande, RS: prevalência e perfil do fumante. J Pneumol. 2002;28:77-83.

22. Malcon MC, Menezes AM, Chatkin M. Prevalência e fatores de risco para tabagismo em adolescentes. Rev Saude Publica. 2003;37:1-7.

23. Souza DPO, Areco KN, Silveira Filho DX. Álcool e alcoolismo entre adolescentes da rede estadual de ensino de Cuiabá, Mato Grosso. Rev Saude Publica. 2005;39:585-92.

24. Vieira DL, Ribeiro MR, Laranjeira RR. Álcool e adolescentes: estudo para implementar políticas municipais. Rev Saude Publica. 2007:41:396-403.

25. Coqueiro RS, Borges LJ, Araújo VC, Pelegrini A, Rodrigues AB. Medidas auto-referidas são válidas para avaliação do estado nutricional na população brasileira? Rev Bras Cineantropom Desempenho Hum. 2009;11:113-9.

26. World Health Organization (WHO). Obesity: preventing and managing the global epidemic. Geneva: WHO; 1998. p. 276.

27. Gucciardi E, Celasun N, Ahmad F, Stewart DE. Eating disorders. Womens Health. 2004;4(suppl 1):1-6.

28. Bosi ML, Uchimura KY, Luiz RR. Eating behavior and body image among psychology students. J Bras Psiquiatr. 2008; 58:150-5.

29. Nunes MA, Olinto MTA, Barros FC, Camey S. Influência da percepção do peso e do índice de massa corporal nos comportamentos alimentares anormais. Rev Bras Psiquiatr. 2001;23:21-7.

30. Stice E, Mazotti L, Weibel D, Agras WS. Dissonance prevention program decreases thin-ideal internalization, body dissatisfaction, dieting, negative affect, and bulimic symptoms: a preliminary experiment. Int J Eat Disord. 2000;27:206-17.

31. Zabinski MF, Pung MA, Wilfley DE, Eppstein D, Winzelberg AJ, Celio A, et al. Reducing risk factors for eating disorders: targeting at-risk women with a computerized psychoeducational program. Int J Eat Disord. 2001;29:401-8.

\section{Correspondence}

Elisa Pinheiro Ferrari

Universidade Federal de Santa Catarina - Centros de Desportos Núcleo de Cineantropometria e Desempeno Humano - UFSC/ $\mathrm{CDS} / \mathrm{NuCIDH}$

Campus Universitário, Trindade, Caixa Postal 476

88040-900 - Florianópolis, SC - Brazil

E-mail: elisaferrari_@hotmail.com 